\begin{tabular}{|l|l|c|}
\hline Volume 1, Number 7 & Research Question Review & 1 AUGUST 2017 \\
\hline
\end{tabular}

\title{
What Critical Factors Do Companies Consider When Selecting Innovation Ideas?
}

By

Troy Montgomery, University of South Florida

$\mathrm{I}$ nnovation management in organizations should be viewed in the context of systems Ithinking. Managers must take a holistic approach to selecting the ideas best suited for their organization.

Decision-making is a major component of innovation management, especially in the early stages of innovation.

Organizations must choose which innovation ideas warrant allocation of scarce resources. The selection of some ideas over others will impact the probability for success of new products or services. Extant literature provides insight into the factors managers should consider during idea selection in the front-end phases of innovation.

The academic literature studied for this research question review article contained both

quantitative and qualitative research. Additionally, a number of related theories impact innovation idea selection including: portfolio theory, contingency theory, systems theory and organization ambidexterity theory.

Organizations are constantly seeking ways to reinvent themselves through innovation. The process of selecting ideas in the early stages of innovation has a significant impact on the probability for success of new products or services. Identifying the critical factors will provide leaders in organizations with a path to future innovation success.
This article provides a consolidated reference for organizations developing innovation decision-making frameworks. One thing seems clear from the research-a reductionist approach towards innovation management will prove inadequate. In other words, there is no "golden ticket" or single answer to the innovation idea selection process. Managers must consider the key factors from literature and then determine the best fit application to their current business environment and constraints.

Keywords: Idea Selection, New Product, New Service, Innovation, Selection Criteria, Decision-making

Copyright $\odot$ 2017, Troy Montgomery. This article is published under a Creative Commons BY-NC license. Permission is granted to copy and distribute this article for non-commercial purposes, in both printed and electronic formats 


\section{Introduction}

According to a recent survey, $93 \%$ of CEO's stated that innovation is critical to their business strategy and long-term success (Koetzier \& Alon, 2013). However, the failure rate for new product introduction is $49 \%$ for the majority of companies, and $29 \%$ amongleaders in innovation (Castellion \& Markham, 2013). Why is innovation such an important topic to executives, yet so difficult to execute?

There are a multitude of explanations for the high failure rate. In fact, a recent article in Harvard Business Review listed 40 reasons new product launches fail. Some leading examples include: a lack of market research, a lack of product differentiation, and a lack of proper funding to launch (Schneider \& Hall, 2011). The Chief Innovation Officer of a large global technology company stated that a critical factor of innovation is how to filter, analyze, prioritize and then select the idea. Other experts, including the Director of a Research University's Center for Entrepreneurship, honed in on a similar need for organizations to improve decision-making regarding innovative ideas. It appears that idea selection is worth further investigation. Thus, this article is intended to provide management in organizations with a summary of current academic research on innovation idea selection.

\section{Methodology}

A literature review was conducted using different combinations of key words in Pro Quest ABI including: "innovation," "selection," "criteria," "new products", and "idea." Peer-reviewed journal articles written after 2010 were filtered with preference given to highly rated innovation journals such as Journal of Product Innovation Management, Technovation, and R\&D Management. A brief abstract review of search results led to more than 50 articles downloaded for inclusion in this analysis. This resulted in a comprehensive view of current academic research related to innovation idea decision-making.

\section{Literature Summary}

The academic literature provides a number of factors for organizations to consider during the innovation decision-making process.

Table 1 provides an overview of findings that researchers agree are critical factors when making decisions on new ideas in an innovation management process.

Factors in Table 1 are labeled as general factors and can be viewed as overarching factors not specific to just the idea selection phase.

Table 1: General Factors in Innovation Idea Selection

\begin{tabular}{|c|c|c|}
\hline Factor & Findings & Sources \\
\hline $\begin{array}{l}\text { Innovation } \\
\text { Type }\end{array}$ & $\begin{array}{l}\text { There is agreement across the literature that there are pri- } \\
\text { marily two types of innovations: incremental and radical. } \\
\text { - Radical: Innovation that creates a high degree of } \\
\text { uncertainty (also called disruptive or discontinuous } \\
\text { innovation). Radical innovation represents a new } \\
\text { paradigm for carrying out some task. It represents } \\
\text { a departure from "existing capabilities in the firm" } \\
\text { and results in new products or services. } \\
\text { Examples: The first iPod \& iTunes, digital } \\
\text { photography, self-driving cars } \\
\text { Incremental: Innovation that does not create much } \\
\text { uncertainty and does not require as high level of } \\
\text { technical expertise to implement (also referred to } \\
\text { as sustaining innovation). Incremental innovations } \\
\text { are typically minor changes to existing products or } \\
\text { services. } \\
\text { Examples: Next year's model of a new au- } \\
\text { tomobile, subsequent versions of computer } \\
\text { processors (Pentium 3, Pentium 4, etc.), } \\
\text { Windows XP to Windows } 7 \text { to Windows } 8\end{array}$ & $\begin{array}{l}\text { Rodgers (2010); } \\
\text { Ritala \& Hermelin- } \\
\text { na-Laukkanen }(2013)\end{array}$ \\
\hline
\end{tabular}


Table 1: General Factors in Innovation Idea Selection (continued)

\begin{tabular}{|c|c|c|}
\hline Factor & Findings & Sources \\
\hline $\begin{array}{l}\text { Criteria Relat- } \\
\text { ed to Innova- } \\
\text { tion Type }\end{array}$ & $\begin{array}{l}\text { Consider the type of innovation when applying criteria to } \\
\text { the decision-making process. } \\
\text { Qualitative criteria are a better fit for Radical ideas } \\
\text { - A scorecard approach with specific questions to } \\
\text { consider, or a version of the Delphi-method, have } \\
\text { all been identified as good approaches to apply to } \\
\text { radical idea decision-making. } \\
\text { Quantitative (i.e., financial) criteria tend to work better } \\
\text { for Incremental ideas } \\
\text { - Organizations can obtain data on products or ser- } \\
\text { vices that are the same or similar to an incremental } \\
\text { innovation. } \\
\text { There is less of a frame of reference for radical in- } \\
\text { novation. When applying decision criteria such as } \\
\text { analyzing the Net Present Value (NPV) or an Inter- } \\
\text { nal Rate of Return (IRR) requirement, it is difficult } \\
\text { to accurately create estimates. Data has shown that } \\
\text { there is a higher probability to kill radical ideas } \\
\text { early in the process using quantitative criteria. This } \\
\text { creates an imbalance in an innovation idea port- } \\
\text { folio leading to less game changing, radical ideas } \\
\text { (see Portfolio of Ideas below). }\end{array}$ & $\begin{array}{l}\text { Schmidt, et al. (2009); } \\
\text { Bessant, et al. (2010); } \\
\text { Cooper (2013); Dooley, } \\
\text { et al. (2000); Salerno, et } \\
\text { al. (2015) }\end{array}$ \\
\hline $\begin{array}{l}\text { Number of De- } \\
\text { cision Points }\end{array}$ & $\begin{array}{l}\text { There is no consensus among researchers on the right num- } \\
\text { ber of decision points in the lifecycle of an innovation. How- } \\
\text { ever, there is agreement that there should be more than one } \\
\text { decision point. } \\
\text { - The New Product Development (NPD) Stage-Gate } \\
\text { method, developed by Cooper, consists of a linear } \\
\text { process of } 5 \text { different gates from idea generation to } \\
\text { product launch. } \\
\text { Managers need to view decision-making as a } \\
\text { progression of gathering more information for a } \\
\text { group of ideas in order to answer questions on their } \\
\text { selected criteria. }\end{array}$ & $\begin{array}{l}\text { Ahn, et al. (2010); Car- } \\
\text { bonell-Foulquié, et al. } \\
\text { (2004); Cooper (2013); } \\
\text { Cooper (1994); Coo- } \\
\text { per (2008); Kock, et al. } \\
\text { (2014); Martinsuo \& } \\
\text { Poskela (2011); Salerno, } \\
\text { et al. (2015); Schmidt, et } \\
\text { al. (2009) }\end{array}$ \\
\hline $\begin{array}{l}\text { Portfolio of } \\
\text { Ideas }\end{array}$ & $\begin{array}{l}\text { Portfolio management has its roots in modern portfolio the- } \\
\text { ory which was originally applied to financial securities. The } \\
\text { objective is to choose a group, or portfolio, of assets that will } \\
\text { maximize expected return while minimizing risk. } \\
\text { - Innovation managers seek to maximize the poten- } \\
\text { tial of new product success by making decisions } \\
\text { on a portfolio of ideas as opposed to one idea at a } \\
\text { time. } \\
\text { - A strategic portfolio of ideas should be advancing } \\
\text { through the organizations innovation process. } \\
\text { - Intentionally choose a target portfolio percentage } \\
\text { for different idea types. One example of portfolio } \\
\text { categories is: "Disruptive," "Progressive," "Con- } \\
\text { tinuous," and "Tactical." } \\
\text { Idea selection should take into account a break- } \\
\text { down of the number and type of ideas that fall into } \\
\text { a specific category. }\end{array}$ & $\begin{array}{l}\text { Martinsuo (2013); Khu- } \\
\text { rana \& Rosenthal (1997); } \\
\text { Kock, et al. (2014); Ab- } \\
\text { bassi, et al. (2014); Ahn, } \\
\text { et al. (2010); Kester, et al. } \\
\text { (2011) }\end{array}$ \\
\hline
\end{tabular}


Table 1: General Factors in Innovation Idea Selection (continued)

\begin{tabular}{|c|c|c|}
\hline Factor & Findings & Sources \\
\hline $\begin{array}{l}\text { Open vs. Closed } \\
\text { Strategies }\end{array}$ & $\begin{array}{l}\text { Innovations management should consist of a balance of op- } \\
\text { posing forces referred to as open and closed strategies. Open } \\
\text { strategies in innovation promote knowledge generation } \\
\text { while closed strategies enhance knowledge integration. } \\
\text { - Examples of open strategies include: providing } \\
\text { employee autonomy and gathering data from con- } \\
\text { sumers early in the process by voting on ideas. } \\
\text { - Examples of closed strategies include: putting in } \\
\text { controls to limit the scope and providing guidelines } \\
\text { on a strategic direction. } \\
\text { It is advantageous to apply a hybrid approach utilizing both } \\
\text { closed (formal) and open (informal) activities throughout } \\
\text { the innovation process. Decision-making is no exception. }\end{array}$ & $\begin{array}{l}\text { Gebert, et al. (2010); } \\
\text { Kock, et al. (2014); King } \\
\text { \& Lakhani (2013) }\end{array}$ \\
\hline
\end{tabular}

Table 2 identifies more specific innovation idea selection factors that have been noted in the literature.

Table 2: Decision Factors in Innovation Idea Selection

\begin{tabular}{|c|c|c|}
\hline Factor & Findings & Sources \\
\hline Strategy & $\begin{array}{l}\text { In evaluating innovation ideas one of the most important fac- } \\
\text { tors is alignment with the firm strategy. Kock, et al. deter- } \\
\text { mined (in a study of } 175 \text { German companies) this to be pos- } \\
\text { itively correlated with both "front-end" innovation success } \\
\text { and overall project portfolio success. Consider the following } \\
\text { in decision-making: } \\
\text { - Vision and goals of the overall organization when } \\
\text { selecting ideas } \\
\text { - Strategic fit with the organization } \\
\text { - Brand fit } \\
\text { Managers should create a strategic category to incorporate in } \\
\text { their evaluation criteria. }\end{array}$ & $\begin{array}{l}\text { Khurana \& Rosen- } \\
\text { thal (1997); Kock, et } \\
\text { al. (2014); Smith, et } \\
\text { al. (2008); Dooley, et } \\
\text { al. (2000); Jonas, et al. } \\
\text { (2013); Cooper (2013); } \\
\text { Martinsuo \& Poske- } \\
\text { la (2011); Abbassi, et } \\
\text { al. (2014); Kester, et al. } \\
\text { (2009); Dooley, et al. } \\
\text { (2000) }\end{array}$ \\
\hline Feasibility & $\begin{array}{l}\text { Is the organization equipped to create the new product or ser- } \\
\text { vice? Khurana \& Rosenthal (1997) studied } 15 \text { business units } \\
\text { at } 11 \text { companies to determine value chain considerations, and } \\
\text { front-end planning regarding feasibility was important to a } \\
\text { majority of the cases. Managers should consider the follow- } \\
\text { ing: } \\
\text { - Do the operations and current assets of the organi- } \\
\text { zation support the idea into a new product launch? } \\
\text { How much complexity is involved with implement- } \\
\text { ing the idea? }\end{array}$ & $\begin{array}{l}\text { Cooper (2013); Khura- } \\
\text { na \& Rosenthal (1997); } \\
\text { Ahn, et al. (2010) }\end{array}$ \\
\hline Market & $\begin{array}{l}\text { Is there a market for the new product? Consider the follow- } \\
\text { ing: } \\
\text { - Market size and potential growth opportunities } \\
\text { - Attractiveness of idea to market } \\
\text { - Market share evaluation and opportunities }\end{array}$ & $\begin{array}{l}\text { Calantone, et al. (1999); } \\
\text { Carbonell-Foulquié, et } \\
\text { al. (2004); Martinsuo \& } \\
\text { Poskela (2011); Ahn, et } \\
\text { al. (2010); Kester, et al. } \\
\text { (2011) }\end{array}$ \\
\hline
\end{tabular}


Table 2: Decision Factors in Innovation Idea Selection (continued)

\begin{tabular}{|c|c|c|}
\hline Factor & Findings & Sources \\
\hline Customer & $\begin{array}{l}\text { Will customers adopt the new product or service? Car- } \\
\text { bonell-Foulquie studied } 77 \text { innovative products and came } \\
\text { away with } 5 \text { key dimensions, including customer acceptance. } \\
\text { Consider the following: } \\
\text { - Likelihood of customer acceptance } \\
\text { Note: it was found that most customer related criteria should } \\
\text { be applied throughout, but has the highest impact on the back } \\
\text { end of the innovations process, closer to launch. }\end{array}$ & $\begin{array}{l}\text { Carbonell-Foulquié, et } \\
\text { al. (2004) }\end{array}$ \\
\hline Technology & \begin{tabular}{|l} 
Is the organization ready for technology advances and re- \\
quirements? Consider the following: \\
- The maturity of technology necessary to support \\
innovation. \\
- The readiness of the market to accept a technology \\
advancement. \\
The technical education of human resources in the \\
organization.
\end{tabular} & $\begin{array}{l}\text { Carbonell-Foulquié, et } \\
\text { al. (2004); Calantone, et } \\
\text { al. (1999); Khurana \& } \\
\text { Rosenthal (1997); Mar- } \\
\text { tinsuo \& Poskela (2011); } \\
\text { Abbassi, et al. (2014); } \\
\text { Smith, et al. (2008) }\end{array}$ \\
\hline Resou & \begin{tabular}{|l} 
Does the organization have the required resources? Consider \\
the following: \\
- The capability of current human resources \\
- The motivation towards innovation (management \& \\
- The availes) \\
- The time to develop and development costs \\
- The knowledge management internally
\end{tabular} & $\begin{array}{l}\text { Khurana \& Rosen- } \\
\text { thal (1997); Abbassi, } \\
\text { et al. (2014); Ahn, et } \\
\text { al. (2010); Smith, et al. } \\
\text { (2008); Dooley, et al. } \\
(2000)\end{array}$ \\
\hline $\begin{array}{l}\text { Financial Op- } \\
\text { portunity }\end{array}$ & $\begin{array}{l}\text { What is the long-term financial opportunity? Consider the } \\
\text { following: } \\
\text { - The short and long-term volume and profitability } \\
\text { - The commercial success probability }\end{array}$ & $\begin{array}{l}\text { Carbonell-Foulquié, et } \\
\text { al. (2004); Khurana \& } \\
\text { Rosenthal (1997); Ab- } \\
\text { bassi, et al. (2014); Kes- } \\
\text { ter, et al. (2009); Trotter } \\
\text { (2011) }\end{array}$ \\
\hline
\end{tabular}

\section{Discussion}

Numerous innovation decision-making factors have been identified in the preceding tables, however the body of research reviewed to identify these factors appears unconnected. Innovation research is fragmented with a wide variety of definitions that impact the outcome and consistency of findings (Ritala, 2013). This makes managerial application of the research very difficult in practice. One cause of the fragmentation of the research can be attributed to the lack of an agreed upon measurement for innovation in organizations. Multiple instruments for measurements have been proposed, but none that researchers and practitioners seem to agree on. Regardless of the fragmentation, the previous tables extract specific factors from innovation research that managers can build into their innovation idea selection processes.

This discussion will attempt to pull together the findings into a manner that managers can apply to their organizations and academics can use to build future research questions. The following sections include a conceptual model that provides a visual representation of key findings, a limitations section that acknowledges limitations of this study, and a future research section that includes opportunities for future lines of research.

\section{Conceptual Model}

A conceptual model (Figure 1) was developed with the intent of providing managers a tool to increase the probability of a successful innovation launch. The following discussion aims to consolidate the factors from Tables 1-3 as well as provide deeper context to the visual.

A high-level organization innovation process, listed in chevrons at the top and bottom of Figure 1, helps set the context for when the idea selection process occurs within organizations. The process steps in the 
Table 3 provides a summary of central theories that are applicable to innovation idea selection.

Table 3: Theory Related to Decision Criteria in Innovation Idea Selection

\begin{tabular}{|c|c|c|}
\hline Theory & Overview \& Application to Research & Sources \\
\hline $\begin{array}{l}\text { Por t f o l i o } \\
\text { Theory }\end{array}$ & $\begin{array}{l}\text { Originally this theory was developed for the financial } \\
\text { markets. An investor's decision to purchase a financial } \\
\text { asset should take into consideration other assets in the } \\
\text { portfolio with the goal to minimize risk and maximize } \\
\text { return. The same concept has recently been applied to } \\
\text { selecting and managing a portfolio of projects. } \\
\text { Applying this logic to innovative ideas will ensure man- } \\
\text { agers are not making an isolated decision on one idea. } \\
\text { They would take into account other ideas when making } \\
\text { a decision. They should continue to gather information } \\
\text { on one potential idea before moving into a subsequent } \\
\text { project phase. Additionally, managers who use this the- } \\
\text { ory develop categories based on pre-determined crite- } \\
\text { ria, and targets for potential risk and reward. For ex- } \\
\text { ample, they may agree that at least } 70 \% \text { of the ideas in } \\
\text { the initial testing phase of implementation are radical } \\
\text { ideas, with a high probability for failure, but also high } \\
\text { potential for reward. }\end{array}$ & $\begin{array}{l}\text { Martinsuo (2013); Khurana \& } \\
\text { Rosenthal (1997); Kock, et al. } \\
\text { (2015); Abbassi,et al. (2014); } \\
\text { Ahn,et al. (2010); Kester, et al. } \\
\text { (2011) }\end{array}$ \\
\hline $\begin{array}{l}\text { Contingency } \\
\text { Theory }\end{array}$ & $\begin{array}{l}\text { This theory explains that there is no one way that is } \\
\text { the "best" way for managers to lead organizations. De- } \\
\text { cisions are contingent on internal and external factors } \\
\text { that may be different. Managers must therefore adapt } \\
\text { to the environment and make adjustments due to the } \\
\text { factors in consideration. } \\
\text { Applying this theory to innovation idea selection would } \\
\text { lead us to believe that the process must be extremely } \\
\text { flexible. For example, in the case of radical innovation } \\
\text { managers, they may determine that the idea is great, } \\
\text { but the market is not ready to adapt to this innovation } \\
\text { (see Diffusion of Innovation by Everett Rodgers). There- } \\
\text { fore, they may decide to shelf an idea for the short term } \\
\text { and revisit it on a continual basis until the time is right. }\end{array}$ & $\begin{array}{l}\text { Salerno, et al. (2015); Martinsuo } \\
\text { (2013) }\end{array}$ \\
\hline $\begin{array}{l}\text { Organiza- } \\
\text { tional Am- } \\
\text { bidexterity } \\
\text { Theory }\end{array}$ & $\begin{array}{l}\text { This theory suggests there are contradictory activi- } \\
\text { ties within organizations that are in a state of natural } \\
\text { tension. An ambidextrous organization is one that is } \\
\text { able to take on tasks that are in some degree of conflict } \\
\text { where trade-offs cannot be entirely eliminated. } \\
\text { Innovation research describes two specific activities } \\
\text { that are in tension. "Exploitation hones and extends } \\
\text { current knowledge, seeking greater efficiency and im- } \\
\text { provement to enable incremental innovation. Explo- } \\
\text { ration entails the development of new knowledge, ex- } \\
\text { perimenting to foster the variation and novelty needed } \\
\text { for more radical innovation" (Andriopoulos \& Lewis, } \\
\text { 2009). Management must be aware of the fact this ex- } \\
\text { ploration causes friction within the organization and } \\
\text { they need to enact strategies to minimize this friction. }\end{array}$ & $\begin{array}{l}\text { Gibson \& Birkinshaw (2004); } \\
\text { Andriopoulos \& Lewis (2009). }\end{array}$ \\
\hline
\end{tabular}


Table 3: Theory Related to Decision Criteria in Innovation Idea Selection (continued)

\begin{tabular}{|l|l|l|}
\hline \multicolumn{1}{|c|}{ Theory } & \multicolumn{1}{|c|}{ Overview \& Application to Research } & \multicolumn{1}{c|}{ Sources } \\
\hline $\begin{array}{l}\text { Systems The- } \\
\text { ory }\end{array}$ & $\begin{array}{l}\text { Systems theory is credited to biologist L. von Berta- } \\
\text { lanffy, who described a system as something made up } \\
\text { of objects, attributes, relationships between objects, and } \\
\text { existing in an environment. He states that investigation } \\
\text { of single parts and processes in biology will not give sci- } \\
\text { entists a true understanding of the phenomenon of an } \\
\text { organism. One must take into account the relationship } \\
\text { of all of the parts within the entire system to truly have } \\
\text { an understanding. Looking only at a single part could } \\
\text { result in misguided conclusions. }\end{array}$ & $\begin{array}{l}\text { Dooley, et al. (2000); Khurana \& } \\
\text { Rosenthal (1997) }\end{array}$ \\
$\begin{array}{l}\text { Likewise, we can apply this same thinking to innova- } \\
\text { tion. Managers must take a holistic view when think- } \\
\text { ing about an innovative idea. This makes a case for a } \\
\text { multi-criteria mind set where decisions are made with } \\
\text { more in mind than simply a financial analysis or differ- } \\
\text { entiation from competitors. }\end{array}$ & \\
\hline
\end{tabular}

initiation and implementation phase were adapted from Rodgers seminal work on innovation diffusion specific to organizations (Rodgers, 2010). Once an idea is developed, organizations select which ideas move into the implementation phase. At this point, the critical factors are taken into consideration and applied to the selection process, which is indicated within the dotted lines.

Notice that the innovation selection process is different for radical vs. incremental innovation ideas. As discussed in Table 1, the type of innovation will drive factors to be considered in a different manner. Note that the linearity in process flow in the incremental innovation is not present for radical innovation. Managers lack a frame of reference for products or services that create a new market or shift their existing market. Radical innovations can take shape quickly or bounce around for longer periods of time before falling out of the funnel for a decision to move forward to launch. On the other hand, companies become more efficient over time with incremental innovations. Driving incremental innovations should become a machine (linear) over time as associates build the necessary skills and proper technology is in place.

Organizational ambidexterity theory applied to innovation tells us that the activities of exploitation and exploration cause tension within the organization. It is vitally important for management to recognize this tension. The ideas that fit in the incremental (right) side of the decision-making model will have less resistance since they attempt to exploit the current technology, human resources, and other existing assets. On the other hand, the ideas on the radical (left) side of the decision-making model will generally have more resistance within the organization due to the radically different nature of the idea. Typically, these ideas will require a major shift of technology, human resources, and other existing assets.

The conceptual model does not visually take into account the "portfolio" of ideas. It should be noted that this is not a single idea in/out approach. Decision-making is actually contingent on other ideas in a true portfolio approach. There is a merging of theories in making portfolio decisions that are contingent on the environment, the resources, project types, the market, and other influences. Notice the circular activity on the radical innovation side. Contingency theory tells us that it is extremely difficult to lock down a clear step by step methodical process. The decision-making is contingent on the confluence of dynamics at play during that particular moment in time. Furthermore, it is essential managers incorporate systems theory in the approach to decision-making. Consideration must be given to all aspects of the organization and the impacts, both positive and negative. In other words, criteria must be in place to help remind managers to consider all the critical factors and not just financial factors.

The decision factors listed: strategic alignment, feasibility, market \& customer, technology and financial 


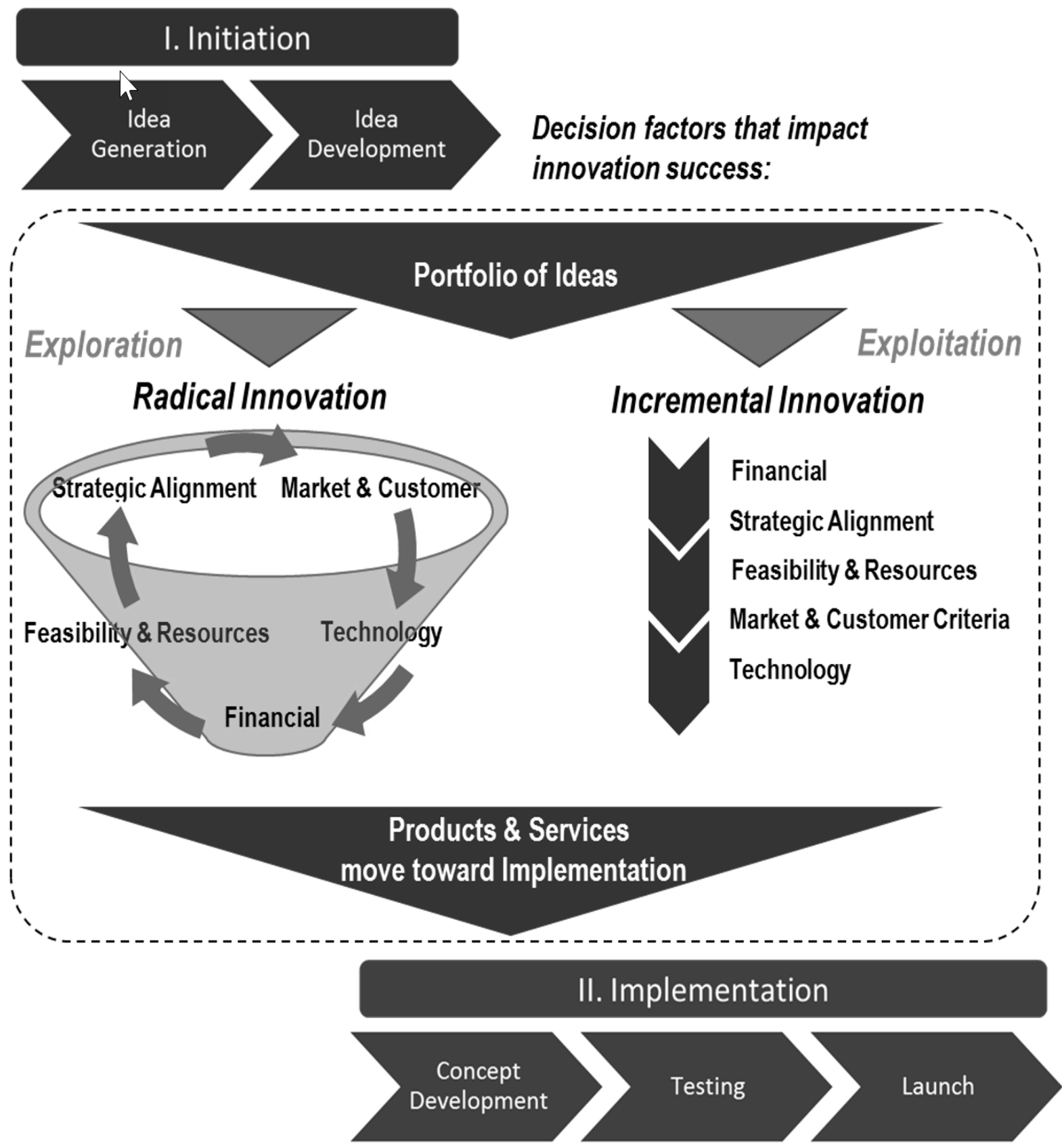

Figure 1: Conceptual Model of Organization Idea Selection Factors

all help to provide managers with a systems perspective. Strategic factors remind decision makers the importance of alignment with business strategy. Feasibility factors prompt managers to evaluate existing resources available and determine if a shift is necessary for the innovation idea. Market \& Customer factors are a necessary pull in the system that indicate to managers the direction to move. If no customer pull is present it would be wise to shift based on market insights. Technology factors provide consideration if the organization has the technology in place, or will need to improve existing technology to meet the demands of the idea. Lastly, financial factors determine if the idea is commercially viable and will create short or long-term returns. Like a true system, the decision factors have a relationship to one another as well as a relationship with the overall system (organization) under consideration. 


\section{Limitations}

First, the tables are focused on scholarly articles published in the innovation literature. Other research disciplines may agree or disagree with the factors included in this article. Next, this research review does not take into account some of the current practitioner related approaches toward innovation. Lean Startup is becoming a popular methodology to apply at both startup companies and innovation groups within large organizations. Lean Startup approaches or articles were not included in the scholarly research results that surfaced for this research question review.

\section{Future Research}

A number of associated research questions were generated based on review of the literature. First, the research reviewed does not address what is happening in practice. What are common factors present in practice today versus what "should" be occurring regarding decision-making in innovation? There seems to be agreement among researchers on some of the decision factors, but there is no agreement on gaps that may exist in practice and academia. Based on a cursory investigation and discussions with subject matter experts, practitioners are relying heavily on un-researched innovation methods and approach-

es. Are these approaches successful? Why are certain decision-making factors used over others? Designing a qualitative study with practitioners close to decision-making in large organizations will uncover gaps and begin to identify current practices. A qualitative study collecting data from innovation practitioners could prove beneficial in gaining an understanding of the existing factors. Subsequent research can then test the existing factors using quantitative methods.

Even when managers have developed an agreed upon decision-making approach to innovation, it doesn't always go as planned. Large organizations are filled with political battles and internal power struggles. Misaligned incentives, organizational structures focused on existing operations, or personal motivations could impact innovation decision-making. Executives tend to over invest in "pet projects" or place an excessive amount of resources in ideas they have generated themselves. Research has been conducted on some of these factors in general. However, there was no discussion of the impact of "pet projects" in innovation decision-making research reviewed for this study.
Regardless of the type of innovation, research has indicated that these criteria are important in innovation management. However, depending on the type of innovation, radical or incremental, there may be differences on how they apply and which are more important. Current research does not provide clear guidance on differences in the criteria by type of innovation.

Table 3 describes theories that have been applied to innovation decision-making. The theories tend to be viewed in a singular fashion. Future research and conceptual models need to incorporate and integrate aspects of all appropriate related theories in innovation idea decision-making. This can prove powerful in providing managers a better model to use in developing innovation strategies and decision-making factors.

\section{Conclusions}

Managers agree that innovation is imperative for organizations to succeed in a continuously changing market place. A product launch failure rate of $49 \%$ signifies that there is a need to improve the way most companies innovate. Determining which ideas to select, and eventually launch, is a major contributor of an organization's ability to launch successful products or services. This article reviewed current academic research to highlight findings and theories related to the research question: What critical decision factors do companies apply when selecting innovation ideas?

Research literature on the topic of innovations is fragmented, largely due to the difficulty in defining a consistent measurement for success in innovation. Without a consistent measurement, it is challenging to establish critical factors relating to the decision-making process. However, a number of common themes have been accepted among researchers. First, there are two different types of innovations referred to as radical (also known as disruptive, discontinuous) and incremental (also known as sustaining). Qualitative decision criteria have been shown as a better fit for radical innovation versus quantitative decision criteria. Quantitative decision criteria including financial measurements such as NPV or IRR are a better fit for incremental innovation ideas. Next, utilizing multiple decision points throughout the innovation management lifecycle is a more effective approach than a single decision point. Likewise, defining and managing a portfolio of innovation ideas, as opposed to managing individual ideas, was discussed through the lens of modern portfolio management theory. Lastly, utilizing a hybrid ap- 
proach of both open and closed decision-making strategies is recommended by researchers. Key decision factors that have been identified by researchers include: strategic alignment, feasibility, market dynamics, technology, resource, customer, and financial factors.

A conceptual model (Figure 1) was developed based on the factors uncovered from this research review. Taking a systems approach to innovation calls for managers to consider the holistic picture when developing a decision-making model. Applying contingency theory challenges decision makers to consider the current environment and constraints when applying criteria, and be open to adjustments when needed.

In closing, further research is warranted regarding innovation decision factors in organizations. Building a conceptual model and study of decision factors

\section{References}

Abbassi, M., Ashrafi, M., \& Tashnizi, E. S. (2014). Selecting balanced portfolios of $\mathrm{R} \& \mathrm{D}$ projects with interdependencies: a cross-entropy based methodology. Technovation, 34(1), 54-63.

Ahn, M. J., Zwikael, O., \& Bednarek, R. (2010). Technological invention to product innovation: A project management approach. International Journal of Project Management, 28(6), 559-568.

Andriopoulos, C., \& Lewis, M. W. (2009). Exploitation-exploration tensions and organizational ambidexterity: Managing paradoxes of innovation. Organization Science, 20(4), 696-717.

Bessant, J., von Stamm, B., Moeslein, K. M., \& Neyer, A. (2010). Backing outsiders: selection strategies for discontinuous innovation. R\&D Management, 40(4), 345-356.

Bonner, J. M., Ruekert, R. W., \& Walker, J. C. (2002). Upper management control of new product development projects and project performance. The Journal of Product Innovation Management, 19233-245.

Brown, S. L., \& Eisenhardt, K. M. (1995). Product development: Past research, present findings, and future directions. Academy of Management Review, 20(2), 343-378.

Brown, S. L., \& Eisenhardt, K. M. (1997). The art of continuous change: Linking complexity theory and time-paced evolution in relentlessly shifting organizations. Administrative Science Quarterly, 1-34.

Calantone, R. J., Benedetto, C. A., \& Schmidt, J. B. (1999). Using the analytic hierarchy process in new product screening. Journal of Product Innovation Management, 16(1), 65-76. using portfolio, systems, and contingency theory together can provide managers with a better model for management of innovations. There is an opportunity to better understand what organizations are currently employing as decision-making factors through a qualitative study using data from innovation practitioners. While the current research is fragmented, it serves as a foundation for future investigation around innovation selection factors.

\section{Review}

This article was accepted under the constructive peer review option. For futher details, see the descriptions at:

http://mumabusinessreview.org/peer-review-options/

Carbonell-Foulquié, P., Munuera-Alemán, J. L., \& Rodriguez-Escudero, A. I. (2004). Criteria employed for go/no-go decisions when developing successful highly innovative products. Industrial Marketing Management, 33(4), 307-316.

Cardinal, L. B. (2001). Technological innovation in the pharmaceutical industry: The use of organizational control in managing research and development. Organization Science, 12(1), 19-36.

Castellion, G., \& Markham, S. K. (2013). Perspective: New Product Failure Rates: Influence of Argumentum ad Populum and Self-Interest. Journal of Product Innovation Management, 30(5), 976-979.

Cooper, R. G. (2013). Invited article: Where are all the breakthrough new products?: Using portfolio management to boost innovation. Research-Technology Management, 56(5), 25-33.

Cooper, R. G. (1994). New products: The factors that drive success. International Marketing Review, 11(1), 60-76.

Cooper, R. G. (2008). Perspective: The Stage-Gate ${ }^{\oplus}$ idea-to-launch process--Update, what's new, and NexGen systems*. Journal of Product Innovation Management, 25(3), 213-232.

D’Alvano, L., \& Hidalgo, A. (2012). Innovation management techniques and development degree of innovation process in service organizations. $R \& D$ Management, 42(1), 60-70.

Dooley, L., Cormican, K., Wreath, S., \& O'Sullivan, D. (2000). Supporting systems innovation. International Journal of Innovation Management, 4(03), 277-297.

Dougherty, D., \& Hardy, C. (1996). Sustained product innovation in large, mature organizations: 
Overcoming innovation-to-organization problems. Academy of Management Journal, 39(5), 1120-1153.

Galbrun, J., \& Kijima, K. J. (2010). Fostering innovation in medical technology with hierarchy theory: Narratives on emergent clinical solutions. Systems Research \& Behavioral Science, 27(5), 523-536.

Gebert, D., Boerner, S., \& Kearney, E. (2010). Fostering team innovation: Why is it important to combine opposing action strategies? Organization Science, 21(3), 593-608.

Gibson, C. B., \& Birkinshaw, J. (2004). The antecedents, consequences, and mediating role of organizational ambidexterity. Academy of Management Journal, 47(2), 209-226.

Girotra, K., Terwiesch, C., \& Ulrich, K. T. (2010). Idea generation and the quality of the best idea. Management Science, 56(4), 591-605.

Hammedi, W., van Riel, A. C., \& Sasovova, Z. (2011). Antecedents and consequences of reflexivity in new product idea screening*. Journal of Product Innovation Management, 28(5), 662-679.

Hart, S., Jan Hultink, E., Tzokas, N., \& Commandeur, H. R. (2003). Industrial companies' evaluation criteria in new product development gates. Journal of Product Innovation Management, 20(1), 22-36.

Jespersen, K. R. (2012). Stage-to-stage information dependency in the NPD process: Effective learning or a potential entrapment of NPD gates? Journal of Product Innovation Management, 29(2), 257-274.

Johne, F. A., \& Snelson, P. A. (1988). Success factors in product innovation: A selective review of the literature. Journal of Product Innovation Management, 5(2), 114-128.

Jonas, D., Kock, A., \& Gemünden, H. G. (2013). Predicting project portfolio success by measuring management quality - a longitudinal study. IEEE Transactions on Engineering Management, 60(2), 215-226.

Kahn, K. B. (2012). The PDMA handbook of new product development. Hoboken, NJ: John Wiley \& Sons.

Kester, L., Hultink, E. J., \& Lauche, K. (2009). Portfolio decision-making genres: A case study. Journal of Engineering \& Technology Management, 26(4), 327-341.

Kester, L., Griffin, A., Hultink, E. J., \& Lauche, K. (2011). Exploring portfolio decision-making pro-

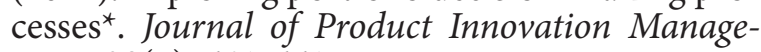
ment, 28(5), 641-661.

Khurana, A., \& Rosenthal, S. R. (1997). Integrating the fuzzy front end of new product development.
Sloan Management Review, 38, 103-120.

Khurana, A., \& Rosenthal, S. R. (1998). Towards holistic "front ends" in new product development. Journal of Product Innovation Management, 15(1), 57-74.

Kim, J., \& Wilemon, D. (2002). Focusing the fuzzy front-end in new product development. $R \& D$ Management, 32, 269-279.

King, A., \& Lakhani, K. R. (2013). Using open innovation to identify the best ideas. MIT Sloan Management Review, (1), 41.

Kock, A., Heising, W., \& Gemünden, H. G. (2015). How ideation portfolio management influences front-end success. Journal of Product Innovation Management, 32(4), 539-555.

Koetzier, W., \& Alon, A. (2013). Why "low risk" innovation is costly. Accenture, May, 12. Retrieved from http://www.accenture.com/SiteCollectionDocuments/PDF/Accenture-Why-Low-Risk-Innovation-Costly.pdf

Krishnan, V., \& Ulrich, K. T. (2001). Product development decisions: A review of the literature. Management Science, 47(1), 1-21.

Liberatore, M. J., \& Stylianou, A. C. (1995). Expert support systems for new product development decision-making: a modeling framework and applications. Management Science, 41(8), 12961316.

Martinsuo, M. (2013). Project portfolio management in practice and in context. International Journal of Project Management, 31(6), 794-803.

Martinsuo, M., \& Poskela, J. (2011). Use of evaluation criteria and innovation performance in the front end of innovation*. Journal of Product Innovation Management, 28(6), 896-914.

Page, A. L., \& Schirr, G. R. (2008). Growth and development of a body of knowledge: 16 years of new product development research, 1989-2004*. Journal of Product Innovation Management, 25(3), 233-248.

Poskela, J., \& Martinsuo, M. (2009). Management control and strategic renewal in the front end of innovation. Journal of Product Innovation Management, 26(6), 671-684.

Rejeb, H. B., Boly, V., \& Morel-Guimaraes, L. (2011). Attractive quality for requirement assessment during the front-end of innovation. TQM Journal, 23(2), 216-234.

Reitzig, M. (2011). Is your company choosing the best innovation ideas?. MIT Sloan Management Review, 52(4), 47.

Riddell, S., \& Wallace, W. A. (2011). The use of fuzzy logic and expert judgment in the R\&D project 
portfolio selection process. International Journal of Technology Management, 53(2-4), 238-256.

Ritala, P., \& Hurmelinna-Laukkanen, P. (2013). Incremental and radical innovation in coopetition-The role of absorptive capacity and appropriability. Journal of Product Innovation Management, 30(1), 154-169.

Rogers, E. M. (2010). Diffusion of innovations, fifth edition. New York: Simon and Schuster.

Salerno, M. S., Gomes, L. V., Silva, D. d., Bagno, R. B., \& Freitas, S. U. (2015). Innovation processes: Which process for which project? Technovation, 3559-70.

Schmidt, J. B., Sarangee, K. R., \& Montoya, M. M. (2009). Exploring new product development project review practices ${ }^{*}$. Journal of Product Innovation Management, 26(5), 520-535.

Schneider, J., \& Hall, J. (2011). Why most product launches fail. Harvard Business Review, April, 2123.

Smith, M., Busi, M., Ball, P., \& Van Der Meer, R. (2008). Factors influencing an organisation's ability to manage innovation: a structured literature review and conceptual model. International Journal of Innovation Management, 12(04), 655-676.

Trotter, P. J. (2011). A new modified total front-end framework for innovation: New insights from health-related industries. International Journal of Innovation Management, 15(05), 1013-1041.

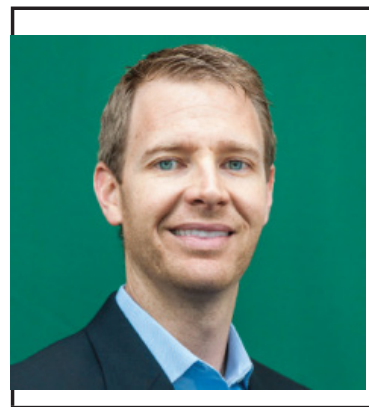

Troy Montgomery is a performance improvement specialist focused on identifying opportunities, solving problems, and working with leaders to implement solutions for change. Troy is currently a Strategy Engagement Leader at Humana and previously served as a management consultant with a global operations consulting firm, SSA\&Company, based in New York, NY. He graduated with honors from the University of Notre Dame with a BS in Mechanical Engineering. He graduated top of his MBA class at the University of Georgia and expects to earn his Doctorate degree in Business Administration (DBA) from the University of South Florida in December, 2017. Troy is a certified Six Sigma Black Belt and Project Management Professional (PMP). 